\title{
Corrigendum: Teachers' perspectives on learners with reading and writing difficulties in mainstream government primary schools in Mauritius
}



Scan this QR code with your smart phone or mobile device mobile device
to read online.

In the original article published, Veerabudren, S., Kritzinger, A. \& Ramasawmy, S.T., 2021, 'Teachers' perspectives on learners with reading and writing difficulties in mainstream government primary schools in Mauritius', South African Journal of Childhood Education 11(1), a1023. https://doi.org/10.4102/sajce.v11i1.1023, Salome Geertsema and Mia le Roux was not included as authors in the published article. The corrected authorship list, associated affiliations and the Author Contributions Statement appears below.

\section{Authors' contributions}

S.V., A.K., S.G. and M.L.R. authors planned the study; S.V. Collected the data and wrote the article. A.K. reviewed the manuscript. S.T.R. carried out the statistical analysis and reviewed the manuscript. All authors provided critical feedback and helped shape the research, analysis and manuscript.

The authors apologise for this error. The correction does not change the study's findings of significance or overall interpretation of the study's results or the scientific conclusions of the article in any way. 


\section{Teachers' perspectives on learners with reading and writing difficulties in mainstream government primary schools in Mauritius}

\begin{tabular}{|c|c|}
\hline \multicolumn{2}{|c|}{$\begin{array}{l}\text { Authors: } \\
\text { Sattiavany Veerabudren }{ }^{1} \text { (D) } \\
\text { Alta Kritzinger }{ }^{1} \text { (I) } \\
\text { Savila T. Ramasawmy }\end{array}$} \\
\hline \multicolumn{2}{|c|}{$\begin{array}{l}\text { Affiliations: } \\
{ }^{1} \text { Department of Speech- } \\
\text { Language Pathology and } \\
\text { Audiology, Faculty of } \\
\text { Humanities, University of } \\
\text { Pretoria, Pretoria, } \\
\text { South Africa }\end{array}$} \\
\hline \multicolumn{2}{|c|}{$\begin{array}{l}{ }^{2} \text { Department of Mathematics, } \\
\text { Faculty of Education, } \\
\text { Mauritius Institute of } \\
\text { Education, Reduit, Mauritius }\end{array}$} \\
\hline \multicolumn{2}{|c|}{$\begin{array}{l}\text { Corresponding author: } \\
\text { Sattiavany Veerabudren, } \\
\text { sattiavany92@gmail.com }\end{array}$} \\
\hline \multicolumn{2}{|c|}{$\begin{array}{l}\text { Dates: } \\
\text { Received: } 28 \text { Apr. } 2021 \\
\text { Accepted: } 24 \text { July } 2021 \\
\text { Published: } 22 \text { Oct. } 2021\end{array}$} \\
\hline \multicolumn{2}{|c|}{$\begin{array}{l}\text { How to cite this article: } \\
\text { Veerabudren, S., Kritzinger, A. } \\
\text { \& Ramasawmy, S.T., 2021, } \\
\text { 'Teachers' perspectives on } \\
\text { learners with reading and } \\
\text { writing difficulties in } \\
\text { mainstream government } \\
\text { primary schools in Mauritius', } \\
\text { South African Journal of } \\
\text { Childhood Education 11(1), } \\
\text { a1023. https://doi. } \\
\text { org/10.4102/sajce.v11i1.1023 }\end{array}$} \\
\hline \multicolumn{2}{|c|}{$\begin{array}{l}\text { Copyright: } \\
\text { (C) 2021. The Authors. } \\
\text { Licensee: AOSIS. This } \\
\text { is licensed under the } \\
\text { Creative Commons } \\
\text { Attribution License. }\end{array}$} \\
\hline \multicolumn{2}{|l|}{ Read online: } \\
\hline 口iㅁ: & $\begin{array}{l}\text { Scan this QR } \\
\text { code with your } \\
\text { smart phone or } \\
\text { mobile device } \\
\text { to read online. }\end{array}$ \\
\hline
\end{tabular}

Background: Although Mauritius has adopted an inclusive education policy for learners with special education needs, it has not yet been implemented. Little is known about how teachers support learners experiencing reading and writing difficulties (RWD) in mainstream government primary schools.

Aim: The aim of the study was to describe the perspectives of mainstream primary school teachers in Mauritius about learners with RWD and inclusive education.

Setting: The data collection took place at the respective schools selected for the study.

Methods: A total of 100 teachers from randomly selected schools in Zone 2, an area with urban and rural schools in Mauritius, were recruited to complete a questionnaire.

Results: The results show that almost all participants had encountered learners with RWD, but they had no training in RWD or specific learning disorders. Thus, participants had inadequate perspectives about the causes, identification and intervention of RWD. By far, the majority of participants viewed special education schools as the best learning environment for learners with RWD and inclusive education as detrimental to learners with RWD. However, the same number of participants $(81.8 \%)$ agreed that extensive teacher retraining will facilitate the integration of learners with RWD in regular schools. Younger participants were more interested in training and more experienced teachers tended to view learners with RWD more positively.

Conclusion: The study supports the need for in-service training of mainstream primary school teachers in RWD and inclusive education and to include the topics in the curriculum of future teachers.

Keywords: reading and writing difficulties; perspectives; teachers; inclusive education; Mauritius; mainstream government primary schools; speech-language therapist; special education needs.

\section{Introduction}

The prevalence of learners experiencing reading and writing difficulties (RWD) has not been documented in Mauritius. Education statistics released by the government in March 2018 showed that the total number of learners attending Special Education Schools was 2656 (Education Statistics-2017 of Republic of Mauritius 2018). Amongst these learners, 144 (5.4\%) were diagnosed with dyslexia. This number only reflects learners diagnosed with the condition and attending special education schools and does not include learners with undiagnosed RWD in mainstream government schools. Learners with RWD fail to read and write at the expected grade level and show consistent below-average performance in reading and spelling (Austin \& Vaughn 2019:34). At present, there are no data on learners with RWD and how the education system is supporting them.

Mauritius has already adopted an inclusive education policy for learners with special education needs in 2006 (Ministry of Education and Human Resources 2006). The policy is based on broader international guidelines such as the Salamanca Statement (UNESCO 1994) and UNESCO (2005), but a policy framework and strategies for implementation were lacking. The Mauritian policy recognises that the concept of 'children with special education needs' extends beyond those with disabilities to include learners who fail academically because of a wide variety of reasons. Stipulations require that learners receive the best possible pedagogical services according to their specific needs, which include adaptation of the curriculum, teaching methods and organisation of the education system and/or provision of additional human and material resources to stimulate efficient and effective learning. Parity and equity of education, inclusion and integration 
of all children in the system are emphasised. A new policy framework and strategy received governmental approval in 2017, which includes several strategic goals to ensure the development of quality materials and equipment for a robust inclusive education system (Ministry of Education and Human Resources 2017). To achieve these strategic goals, the role of teachers and their teaching approaches are important.

In an inclusive education system, the role of teachers is to extensively and creatively adapt their teaching methods and implement specific interventions for learners with RWD. There should be collaborative teamwork between teachers and professionals such as psychologists, speech-language therapists, audiologists and occupational therapists. Teamwork allows the diagnosis of learners with RWD so that their specific learning disorder can be appropriately addressed in the intervention (Paterlini et al. 2019:4). Teachers are largely responsible to identify learners with RWD, refer them for diagnosis and collaborate with members of the multidisciplinary team to adapt the curriculum (Allen, Matthews \& Parsons 2013:114; Vasudevan 2017:310; Vaughn \& Parsons 2013:81). Hence, teachers require training to familiarise themselves with the signs and causes of RWD to identify learners in their class as early as possible (Hollenweger 2011:454).

It appears that teachers in mainstream schools may have insufficient knowledge of signs and causes of RWD in their learners. Studies from India, Egypt and Tanzania highlight the minimal awareness and understanding of teachers about learners who show symptoms of hyperactivity, short attention span and difficulties with literacy and numeracyrelated tasks in class (Essa \& El-Zeftawy 2015:84; Kafonogo \& Bali 2013:60; Kamala \& Ramganesh 2013:172). Teachers may feel fearful, upset, worried, unprepared and inadequate but may also have a sense of increased responsibility when they encounter such learners in their classes (Ateş, Yildirim \& Yildiz 2010:48). With adequate training in the inclusive education approach, teachers can have positive attitudes and be prepared to support the system and learners (Pit-ten Cate et al. 2018:55). The aim of this study was to describe the perspectives of mainstream primary school teachers in Mauritius about learners with RWD and inclusive education, whether there are factors associated with their views, and to what extent they are ready to support learners with RWD in a regular classroom. Whilst the Ministry of Education in Mauritius adopted an inclusive education policy, but has not yet implemented the approach, the study may reveal caveats to address preparing teachers for inclusive education for learners with specific learning disorders such as dyslexia that underlie their RWD.

\section{Research methods and design}

A descriptive research design using a survey questionnaire was employed. The schools in Mauritius are distributed in four zones. Primary school teachers were recruited from government schools in Mauritius in Zone 2. Zone 2 has an equal number of urban and rural schools and is, therefore, representative of the teaching environments of teachers in Mauritius. A simple random sampling method was used to select primary schools to participate in the study. A list of government primary schools located in Zone 2 was obtained from the Department of Primary Education. The schools were divided into urban and rural locations and allotted numbers. Using a lottery method, an even number of schools according to the urban and rural ratio was selected and requested to participate in the study. After obtaining permission for data collection from all selected schools, teachers from each school were informed about the study, approached to participate and requested to give informed consent to complete the questionnaire. A total of 20 schools participated and four to six teachers per school agreed to participate in the study. The sample size was 100 primary school teachers. As inclusion criteria, all participants had to be qualified with at least a diploma in primary school education and should have been teaching learners in a mainstream government primary school. They should have been between 25 and 60 years of age with a minimum of 3 years of working experience.

The sample of participants included mostly females in their later adulthood with degree qualifications and experienced in teaching. Their multilingual background reflects the prevalence of multilingualism in Mauritius and in school classrooms (see Table 1).

The perspectives of teachers were determined by means of a questionnaire in English, adapted from Lopes and Crenitte (2013) and Alawadh (2016). The questionnaire comprised four sections according to topics related to the demographic characteristics of the participants, their perspectives about learners with RWD and inclusive education and what they are doing to support such learners in mainstream government primary schools. A specific time was arranged where participants from each school completed the questionnaires individually at the same time in one room. The researcher gave basic instructions regarding the questionnaire and reminded them not to disclose their name on the questionnaire as data had to remain anonymous. The researcher was available for queries regarding the questions, but no information to influence their answers was given.

Statistical Package for the Social Sciences used for complex statistical data analysis in research version 16 software was used to analyse the data quantitatively in three phases, descriptive analysis, determining associations between variables and factor analysis. Descriptive statistics derived from the questionnaire responses were analysed and expressed as means, standard deviations and percentages according to the respective categories. Descriptive responses were analysed as main themes. The chi square test was used to determine the relationships between the study variables. Data were further reduced into a small number of key dimensions (factors) using principal component analysis. This was done by determining the degree to which a certain 
TABLE 1: Teacher characteristics $(n=100)$.

\begin{tabular}{|c|c|c|c|c|c|}
\hline \multirow[t]{2}{*}{ Demographic variable } & \multirow[t]{2}{*}{ Mean } & \multirow[t]{2}{*}{ SD } & \multirow[t]{2}{*}{ Range } & \multicolumn{2}{|c|}{ Value } \\
\hline & & & & $n$ & $\%$ \\
\hline Age (years) & 36.59 & 7.47 & $22-59$ & - & - \\
\hline Gender & - & - & - & & \\
\hline Female & - & - & - & 71 & 71 \\
\hline Male & - & - & - & 29 & 29 \\
\hline \multicolumn{6}{|l|}{ Education } \\
\hline Certificate & - & - & - & 4 & 4 \\
\hline Diploma in Education & - & - & - & 29 & 29 \\
\hline $\begin{array}{l}\text { Degree in Education or } \\
\text { other fields }\end{array}$ & - & - & - & 55 & 55 \\
\hline Postgraduate degree & - & - & - & 12 & 12 \\
\hline \multicolumn{6}{|l|}{$\begin{array}{l}\text { Teaching experience } \\
\text { (years) }\end{array}$} \\
\hline $0-10$ & - & - & - & 40 & 40 \\
\hline $11-30$ & - & - & - & 55 & 55 \\
\hline$>31$ & - & - & - & 5 & 5 \\
\hline \multicolumn{6}{|l|}{ Languages } \\
\hline Home language & - & - & - & - & - \\
\hline Mauritian Creole & - & - & - & 100 & 100 \\
\hline \multicolumn{6}{|l|}{ Additional languages } \\
\hline French & - & - & - & 100 & 100 \\
\hline English & - & - & - & 100 & 100 \\
\hline Hindi & - & - & - & 24 & 24 \\
\hline $\begin{array}{l}\text { Arab, German, Mandarin, } \\
\text { Marathi, Sanskrit, Sign } \\
\text { language, Urdu }\end{array}$ & - & - & - & 27 & 27 \\
\hline \multicolumn{6}{|l|}{$\begin{array}{l}\text { Language used to teach } \\
\text { in class }\end{array}$} \\
\hline $\begin{array}{l}\text { French, English and } \\
\text { Mauritian Creole }\end{array}$ & - & - & - & 64 & 64 \\
\hline French and English only & - & - & - & 25 & 25 \\
\hline Creole and French only & - & - & - & 1 & 1 \\
\hline Creole and English only & - & - & - & 1 & 1 \\
\hline Creole only & - & - & - & 1 & 1 \\
\hline French only & - & - & - & 2 & 2 \\
\hline English only & - & - & - & 7 & 7 \\
\hline \multicolumn{6}{|l|}{ Subjects taught } \\
\hline General subjects & - & - & - & 97 & 97 \\
\hline Non-academic subjects & - & - & - & 3 & 3 \\
\hline \multicolumn{6}{|l|}{$\begin{array}{l}\text { Number of learners in } \\
\text { class }\end{array}$} \\
\hline $15-24$ & - & - & - & 26 & 26 \\
\hline $25-34$ & - & - & - & 50 & 50 \\
\hline 35 and above & - & - & - & 24 & 24 \\
\hline
\end{tabular}

SD, standard deviation.

response in the questionnaire correlated with a certain factor. By summarising the relationships amongst variables in a concise way, existing relationships in the questionnaire responses could be more readily understood.

\section{Ethical considerations}

Ethical clearance was obtained from the University's Ethics Committee (HUM018/0520) and the Ministry of Education of Mauritius.

\section{Results}

The quantitative data are presented in percentages and standard deviations to show the participants' perspectives about the causes, symptoms and the involvement of a multidisciplinary team in learners with RWD. Participants' own descriptive responses of strategies to assist learners with RWD in regular classrooms are presented as main themes and percentages. Significant associations between variables were considered on $p<0.05$ and the factor analysis results are presented as Eigen values.

\section{Participants' teacher training about reading and writing difficulties, their familiarity with diagnostic terms, causes of reading and writing difficulties and the multidisciplinary team involved in the intervention for learners with reading and writing difficulties}

The results showed that only $51 \%$ of participants had an orientation about different communication disorders and specific learning disorders during their teacher training. By far, the majority $(78 \%)$ did not receive any information about the roles of audiologists and speech-language therapists in schools. The diagnostic terms related to RWD they were familiar with varied. Participants were mostly familiar with dyslexia (87\%) and attention-deficit hyperactivity disorder (57\%). They were less familiar with terms such as phonological disorder $(41 \%)$, specific learning disorder (40\%), dyscalculia (38\%), dysgraphia $(33 \%)$ and central auditory processing disorder $(20 \%)$.

According to most participants, the reason for RWD was intellectual disability ( $82 \%$ ) and a lack of parental involvement and limited interest in their child (79\%). Seventy per cent indicated that RWD may be because of behavioural problems such as attention deficit and $69 \%$ noted that it might be secondary to sensory deficits such as hearing difficulties and poor vision. Only $43 \%$ of teachers indicated that teaching methods contributed to RWD. Most participants (70.7\%) responded that RWD or specific learning disorder can be outgrown, showing that they may not fully understand the underlying nature of difficulties with reading and writing.

Participants were also asked which professionals they would consult when they suspected that a learner had RWD. Most participants (65\%) said they will refer the learner to the school principal and only $29 \%$ would ask for the assistance of a support teacher. Their answer may be related to the limited availability of support teachers in mainstream schools in Mauritius. Very few participants selected professionals involved in the diagnosis and intervention of RWD, such as psychologists $(26 \%)$, speech-language therapists $(8 \%)$ and occupational therapists $(6 \%)$. However, $96 \%$ of participants reported to have encountered learners with RWD in their teaching career.

\section{Perspectives on identification and support of learners with reading and writing difficulties}

To facilitate the presentation of the findings as shown in Table 2, the responses on the 4-point Likert scale were reduced to two categories only, 'strongly agreed/agreed' and 'disagreed' or 'strongly disagreed'. Most participants $(64.3 \%)$ were confident that they would be able to identify learners with RWD, but more $(67.7 \%)$ reported that they do not have sufficient knowledge to support them. A positive result is shown as $77.7 \%$ of participants believed that a learner with RWD or a specific learning disorder can be identified before the child is 8 years old (see Table 2 ). 
TABLE 2: Participants' perspectives on their ability to identify and support learners with reading and writing difficulties.

\begin{tabular}{lccc}
\hline Statements & $\begin{array}{c}\text { Agreed/strongly } \\
\text { agreed } \\
\text { \% }\end{array}$ & $\begin{array}{c}\text { Disagreed/strongly } \\
\text { disagreed } \\
\%\end{array}$ & SD \\
\hline $\begin{array}{l}\text { I have enough knowledge about } \\
\text { RWD to be able to identify such } \\
\text { learners. }\end{array}$ & 64.3 & 35.7 & 5.1 \\
$\begin{array}{l}\text { I have enough knowledge about } \\
\text { RWD to be able to support such } \\
\text { learners. }\end{array}$ & 32.3 & 67.7 & 16.2 \\
$\begin{array}{l}\text { RWD cannot be identified until a } \\
\text { learner is 8 years old. }\end{array}$ & 22.3 & 77.7 & 22.2 \\
$\begin{array}{l}\text { The future of literacy achievement } \\
\text { for learners with RWD is extremely } \\
\text { limited. }\end{array}$ & 60.6 & 39.4 & 2.1 \\
\hline
\end{tabular}

RWD, reading and writing difficulties; SD, standard deviation.

TABLE 3: Participants' perspectives about characteristics of learners with reading and writing difficulties.

\begin{tabular}{lccc}
\hline Statements & $\begin{array}{c}\text { Agreed/strongly } \\
\text { agreed } \\
\text { \% }\end{array}$ & $\begin{array}{c}\text { Disagreed/strongly } \\
\text { disagreed } \\
\text { \% }\end{array}$ & SD \\
\hline $\begin{array}{l}\text { Learners with RWD are good at art, } \\
\text { music, drama, sports, design. }\end{array}$ & 76.7 & 23.3 & 1.0 \\
$\begin{array}{l}\text { Learners with RWD are more creative } \\
\text { than other learners who allow them } \\
\text { to overcome their difficulties. }\end{array}$ & 65.7 & 34.3 & 1.0 \\
$\begin{array}{l}\text { Learners with RWD try harder than } \\
\text { other learners to read. }\end{array}$ & 59.6 & 40.4 & 3.0 \\
$\begin{array}{l}\text { It is likely that learners with RWD will } \\
\text { show behaviour problems in regular } \\
\text { classrooms. }\end{array}$ & 30.3 & 69.7 & 9.1 \\
$\begin{array}{l}\text { Most learners with RWD try to } \\
\text { complete their classwork and } \\
\text { homework. }\end{array}$ & 70.7 & & \\
\hline
\end{tabular}

RWD, reading and writing difficulties; SD, standard deviation.

\section{Perspectives on characteristics of learners with reading and writing difficulties}

As shown in Table 3, most participants regarded learners with RWD as being good at art, music and other extracurricular activities $(76.7 \%)$ and that they are more creative $(65.7 \%)$. A total of 59.6\% strongly agreed/agreed that learners with RWD often try harder to read and can complete their class/ homework (70.7\%) on their own. Participants, therefore, had a fair perspective about those characteristics of learners with RWD that could facilitate their inclusion in regular schools. Most participants strongly disagreed/disagreed (69.7\%) with the statement that learners with RWD are likely to demonstrate behaviour problems in regular classrooms. The majority $(60.6 \%)$ believed that the future literacy achievements for learners with RWD are extremely limited.

\section{Perspectives on learners with reading and writing difficulties in inclusive education}

By far, the majority of participants $(81.8 \%)$ were of the opinion that learners with RWD should be enrolled in a special education needs school rather than in a mainstream school within an inclusive education approach. As shown in Table 4, there was little variation in views that inclusive education may be detrimental for typical learners $(63.7 \%$, $61.6 \%$ and $65.6 \%$ ). The majority $(63.7 \%)$ responded that a regular classroom will not promote the academic growth of learners with RWD. Almost the same number of participants $(61.6 \%)$ strongly agreed/agreed that the behaviour of learners with RWD may set a bad example for typically
TABLE 4: Participants' perspectives learners with reading and writing difficulties in inclusive education.

\begin{tabular}{|c|c|c|c|}
\hline Statements & $\begin{array}{l}\text { Agreed/strongly } \\
\text { agreed } \\
\%\end{array}$ & $\begin{array}{l}\text { Disagreed/strongly } \\
\text { disagreed } \\
\%\end{array}$ & SD \\
\hline $\begin{array}{l}\text { Learners with RWD should be } \\
\text { enrolled and followed up in } \\
\text { appropriate special educational } \\
\text { needs schools. }\end{array}$ & 81.8 & 18.2 & 5.1 \\
\hline $\begin{array}{l}\text { Integration of learners with RWD } \\
\text { offers mixed group interaction } \\
\text { that will foster understanding and } \\
\text { acceptance of differences amongst } \\
\text { learners. }\end{array}$ & 53.6 & 46.4 & 4.0 \\
\hline $\begin{array}{l}\text { Being in regular classrooms will } \\
\text { promote the academic growth of } \\
\text { learners with RWD. }\end{array}$ & 36.3 & 63.7 & 8.1 \\
\hline $\begin{array}{l}\text { The behaviour of learners with } \\
\text { RWD will set a bad example for } \\
\text { learners without difficulties. }\end{array}$ & 38.4 & 61.6 & 15.2 \\
\hline $\begin{array}{l}\text { Integration of learners with RWD } \\
\text { will require extensive retraining of } \\
\text { regular classroom teachers. }\end{array}$ & 81.8 & 18.2 & 1.0 \\
\hline $\begin{array}{l}\text { The extra attention learners with } \\
\text { RWD will be to the detriment of } \\
\text { the other learners. }\end{array}$ & 74.7 & 25.3 & 2.0 \\
\hline $\begin{array}{l}\text { Learners with RWD are socially } \\
\text { isolated in the regular classroom. }\end{array}$ & 48.5 & 51.5 & 3.0 \\
\hline $\begin{array}{l}\text { I would welcome learners with } \\
\text { RWD in my classroom and would } \\
\text { work with them. }\end{array}$ & 68.4 & 31.6 & 6.3 \\
\hline $\begin{array}{l}\text { Modification of coursework for } \\
\text { learners with RWD would be } \\
\text { difficult to justify to other } \\
\text { learners. }\end{array}$ & 65.6 & 34.4 & 2.1 \\
\hline
\end{tabular}

RWD, reading and writing difficulties; SD, standard deviation

achieving learners and that the extra attention given to learners with RWD will be to the detriment of other learners. According to $65.6 \%$ of the participants, it will also be challenging to justify to typically achieving learners the modification of coursework for learners with RWD.

As further shown in Table 4, participants were almost evenly divided in responses that learners with RWD in inclusive classrooms may foster better understanding and acceptance of differences amongst learners, and that learners with RWD are socially isolated in the regular classroom. The result may show that participants were uncertain about the advantages of inclusive education for learners with RWD. A higher percentage $(68.4 \%)$ of participants expressed their willingness to welcome learners with RWD in their classroom. This is an interesting result as only $18.2 \%$ expressed the view earlier that learners with RWD should not be enrolled in special education schools. This may reflect a positive attitude towards learners with RWD. A strong recognition of training needs may be seen in the following result (Table 4). By far, the majority of participants $(81.8 \%)$ strongly agreed/agreed with the statement that integration of learners with RWD will require extensive retraining of regular classroom teachers.

\section{Participants' strategies to assist learners with reading and writing difficulties in regular classrooms}

Participants were also asked to describe strategies that they would employ to support learners with RWD (see Table 5). Most participants (92\%) responded to this open-ended 
question. Responses could be divided into two categories. The majority (64.1\%) of the descriptions involved assistance to learners with RWD outside the regular classroom, with active engagement with a multidisciplinary team of specialists such as psychologists, speech-language therapists and occupational therapists. Far less $(35.86 \%)$ responses included strategies that participants would employ within their classrooms. The limited number of within-classroom strategies mentioned by participants may be related to their views in Table 4 that learners with RWD should be enrolled in special education schools.

It is, however, interesting to observe that participants are resourceful about strategies to be used in their classroom to assist learners with RWD, even though some only had an orientation about communication disorders and specific learning disorders during their teacher training. Some participants also suggested strategies that are in accordance with the principles of inclusive education, such as peer teaching and mixed ability classrooms. However, most responses (14.5\%) again point to a special education perspective and not to inclusive education (see Table 5).

\section{Significant associations amongst participants' age intervals, qualifications and years of experience and the way they responded to questions}

Using the chi-square test, further analyses were performed to determine whether there were any statistically significant associations between participants' perspectives expressed in the questionnaire and their age, qualifications and years of experience. Results indicated that there was a significant association $(p<0.05)$ between the participants' age and agreement or disagreement with the statement 'Integration

TABLE 5: Strategies suggested by participants to assist learners with reading and writing difficulties.

\begin{tabular}{lll}
\hline $\begin{array}{l}\text { Strategies involving assistance from outside the regular } \\
\text { classroom }\end{array}$ & $n$ & $\%$ \\
\hline $\begin{array}{l}\text { 1. Special education with specialised educators (individual } \\
\text { attention) }\end{array}$ & 21 & 14.5 \\
$\begin{array}{l}\text { 2. De-loading the curriculum (e.g. language exemptions) } \\
\text { 3. Regular visits of psychologists and other therapists }\end{array}$ & 17 & 11.7 \\
$\begin{array}{l}\text { 4. Use of adapted books and resources } \\
\text { 5. Support teachers }\end{array}$ & 10 & 7.6 \\
$\begin{array}{l}\text { 6. Categorising learners based on their abilities and } \\
\text { difficulties to be able to focus on essential learning }\end{array}$ & 9 & 6.9 \\
competencies & 9 & 6.2 \\
7. Decrease student-teacher ratio & 6 & 4.1 \\
8. Training of normal curriculum educators to identify & 5 & 3.5 \\
these learners & & \\
9. Remedial work & 4 & 2.8 \\
Strategies to use within their classrooms & $\boldsymbol{n}$ & $\%$ \\
1. Use of teaching aids & 12 & 8.3 \\
2. Use of multisensory teaching modalities & 9 & 6.2 \\
3. Activity-based lessons & 9 & 6.2 \\
4. Peer teaching, mixed ability classrooms & 6 & 4.1 \\
5. Repetition exercises & 6 & 4.1 \\
6. Phonological activities (phonics) & 5 & 3.5 \\
7. Vocabulary building exercises & 3 & 2.1 \\
8. Motivate them & 2 & 1.4 \\
\hline
\end{tabular}

of learners with RWD will necessitate extensive retraining of regular classroom teachers'. A total of $44.8 \%$ participants within the age range of 20-30 years strongly agreed and $61.5 \%$ of participants between 31 and 40 years old agreed to additional training. It, therefore, appears that younger participants were more likely to agree to training to support learners with RWD in an inclusive education system.

A significant association was also found between age and the statement related to the future literacy achievements for learners with RWD. A total of 32.6\% participants 31-40 years old and $30.2 \%$ of participants $41-60$ years old agreed that literacy achievements for learners with RWD are limited. It, therefore, appears that older participants had a more negative perspective on the ability of learners with RWD to achieve literacy. Another significant association $(p<0.05)$ was found for the statement 'most learners with RWD try to complete their classwork and homework' and participants' qualification level. A total of $65.7 \%$ participants with a lower qualification (diploma in teaching on a primary level) disagreed that learners with RWD try to complete their classwork and homework.

Further analysis revealed significant associations $(p<0.005)$ between the statements 'Learners with RWD are good at arts, music, drama, sports and design', 'Integration of learners with RWD will necessitate extensive retraining of regular classroom teachers', 'I would welcome learners with RWD in my class and would work with them' and participants' years of teaching experience. Forty two per cent to $44 \%$ of participants with 11-30 years of experience in teaching agreed to these statements. It appears that more experienced teachers tended to view learners with RWD in an inclusive classroom more positively and agreed that teachers needed extensive training.

\section{Significant associations between participants' perspectives about identification and intervention of reading and writing difficulties and their views on learners with reading and writing difficulties in an inclusive classroom}

The chi-square test was further used to investigate the associations between the participants' responses about the identification and intervention for learners with RWD and their perspectives on learners with RWD in their classrooms. The results revealed significant associations $(p<0.05)$ between the participants' confidence about identification of learners with RWD and their agreement to statements that emphasised characteristics about learners with RWD that may facilitate their inclusion (see Table 3). Participants who were more confident about their ability to identify learners with RWD tended to view learners with RWD more positively, agreeing that they can achieve in certain areas. Statements included whether learners with RWD are generally good at non-academic subjects $(p=0.006)$ and will benefit from an inclusive education approach as it will foster an understanding of their difficulties and promote their social acceptance ( $p=$ 0.04 ) and the view that an inclusive classroom will promote 
the academic progress of learners with RWD $(p=0.004)$. Participants who were most confident that they could identify learners with RWD also agreed that learners with RWD make extra efforts to meet academic demands $(p=0.04)$ although isolation in class is anticipated in a regular classroom $(p=0.04)$.

There were also significant relationships $(p<0.05)$ between participants who stated they lacked knowledge about intervention of learners with RWD and their perspectives on efforts of learners with RWD when included in an inclusive classroom. Those participants were more likely to agree that learners with RWD try to complete their classwork and homework $(p=0.04)$, but that extra attention given to learners with RWD will be detrimental to typical learners $(p=0.00)$. More importantly, participants, who stated that they do not know enough about RWD intervention, reported that they would welcome learners with RWD in their class and work with them $(p=0.01)$. The same participants were also more likely to agree that retraining of all regular classroom teachers is required to successfully integrate learners with $\operatorname{RWD}(p=0.01)$.

\section{Factor analysis of statements and responses about identification and intervention of reading and writing difficulties and views on learners with reading and writing difficulties in an inclusive classroom}

Factor analysis is a technique used to summarise many variables into fewer factors. This technique extracts maximum common variance from all variables and puts them into a common score. Thus, the set of possible correlated variables was converted into a reduced set of uncorrelated variables that capture most of the variation in the original data. In addition to the descriptive analysis conducted as shown in Tables 2-4, and chi-square tests carried out to investigate the associations, factor analysis was used as a reduction method to extract commonalities from statements in Tables $2-4$.

The factor analysis carried out for statements pertaining to participants' perspectives about identification and intervention

TABLE 6: Component score coefficient matrix for participants' perspectives about identification and intervention of reading and writing difficulties.

\begin{tabular}{lcc}
\hline Statements & \multicolumn{2}{c}{ Component score coefficient matrix } \\
\cline { 2 - 2 } & $\begin{array}{c}\text { Component 1: } \\
\text { Perspectives about } \\
\text { identification } \\
\text { and intervention } \\
\text { of RWD }\end{array}$ & $\begin{array}{c}\text { Misconceptions } \\
\text { about RWD }\end{array}$ \\
\hline $\begin{array}{l}\text { Participants had enough knowledge } \\
\text { about RWD to be able to identify such } \\
\text { learners. }\end{array}$ & $0.433^{*}$ & 0.106 \\
$\begin{array}{l}\text { Participants had enough knowledge } \\
\text { about RWD to be able to support such }\end{array}$ & $0.488^{*}$ & 0.038 \\
learners. & & $0.477^{*}$ \\
$\begin{array}{l}\text { Participants believed that RWD cannot } \\
\text { be identified until a learner is 8 years } \\
\text { old. }\end{array}$ & 0.358 & $0.843^{*}$ \\
$\begin{array}{l}\text { Participants believed that the future } \\
\text { of literacy achievement for learners } \\
\text { with RWD is extremely limited. }\end{array}$ & 0.127 & \\
\hline
\end{tabular}

RWD, reading and writing difficulties.

* Items with highest Eigen values considered to describe the component. of RWD (Table 2) identified two components (factors) as shown in Table 6. Component 1 was made up of variables regarding the participants' perspectives about the identification and intervention of learners with RWD. In that respect, Component 1 was described as 'Perspectives about identification and intervention of RWD'. Whilst Component 2 relates to variables that represented misconceptions about RWD, such as 'RWD cannot be identified until 8 years of age', 'Learners with RWD have poor literacy achievements'. Perspectives about identification and intervention of RWD were found to be more important than the misconceptions about RWD. The component consists of significant information about the participants' confidence about how they currently identify and support learners with RWD.

Furthermore, the principle component analysis enabled the extraction of six components from statements related to participants' perspectives about characteristics and their views on learners with RWD in an inclusive classroom (Tables 3 and 4). Only those components with higher loadings (Eigen values) were included. As shown in Table 7, Component 1 identifies variables that were described to be in favour of inclusive education for learners with RWD. Component 2 included variables that showed that the participants agree to the integration of learners with RWD in inclusive education but also highlights the need for training of mainstream primary school teachers. Component 2 was described as integration in inclusive education which is subject to the training of teachers. Component 3 consisted of variables regarding behavioural problems and drawbacks of teaching learners with RWD in a regular classroom that the participants anticipated (described as behaviour problems and other issues). Component 4 incorporated all the characteristics about learners with RWD that can facilitate their inclusion in a regular classroom, such as being more creative and that they are good at non-academic subjects or activities. Component 4 relates to the characteristics of learners with RWD that can facilitate inclusion in a regular classroom.

Lastly, Components 5 and 6 are variables that show the attempts of learners with RWD to read and write in a class. Component 5 can be described as 'Learners with RWD try to read' and Component 6 can be described as 'learners with RWD try to meet' the classroom academic demands. Components 1, 2 and 3, consisting of variables that were generally in favour of inclusive education for learners with RWD and highlighted the need for training of mainstream primary school teachers, were found to be most important in this analysis. This shows that learners with RWD can be taught adequately in regular classrooms if the education system and teachers are appropriately equipped with resources along with professional development training. Also, learners with RWD have characteristics other than difficulties to read and write that can not only facilitate their integration amongst typically achieving learners but also may contribute to the overall learning process of all learners in the class. 
TABLE 7: Component score coefficient matrix for participant's perspectives about characteristics and their views on learners with reading and writing difficulties in an inclusive classroom.

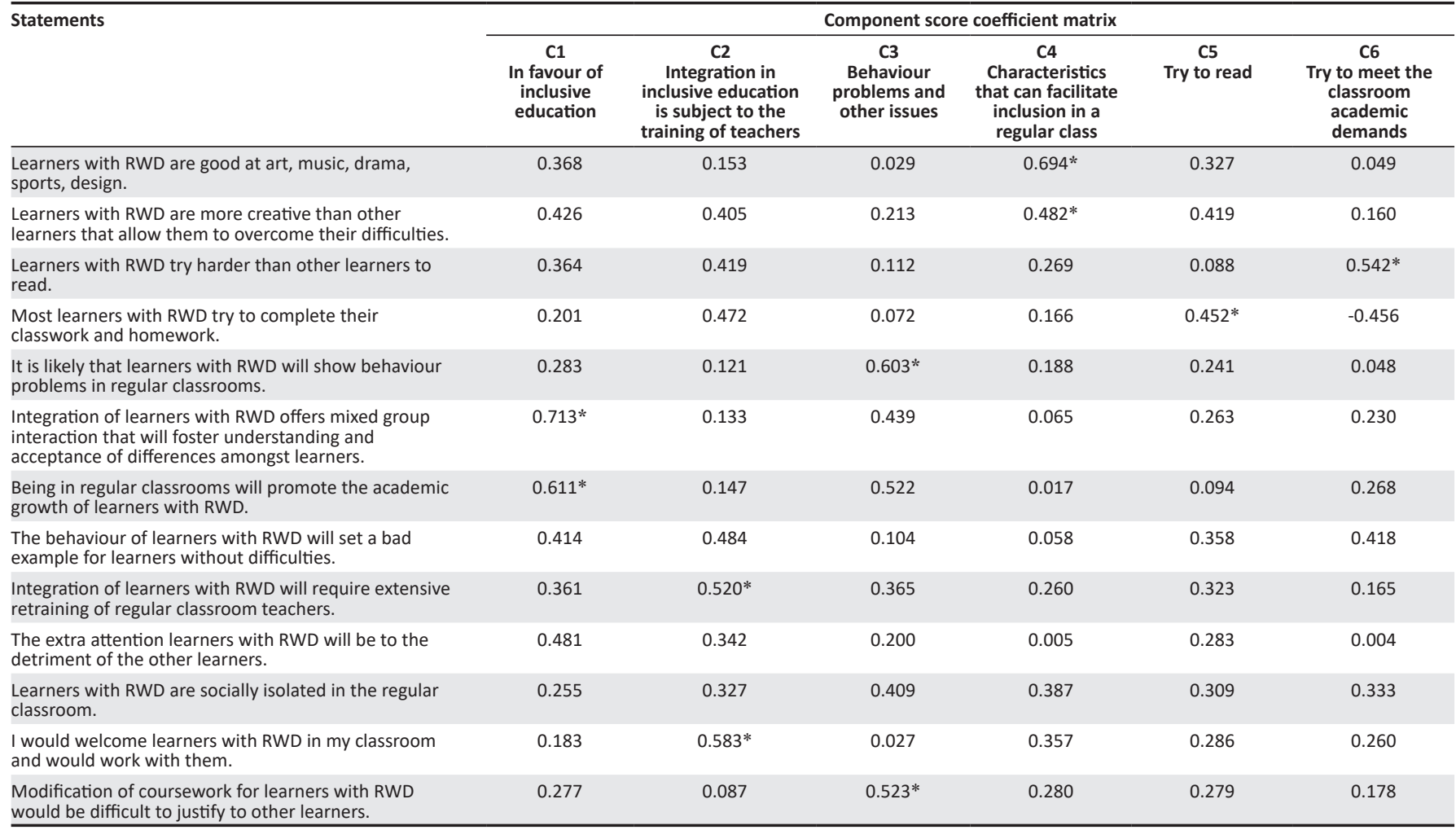

RWD, reading and writing difficulties.

* Items with highest Eigen values considered to describe the component.

\section{Discussion}

The participants' familiarity with RWD, their perspectives on its causes, identification and intervention options in an inclusive education setting are discussed in relation to the training they received, similar research studies and within an inclusive education framework. Associations found between the participants' age, qualification and years of experience are also critically discussed and compared to their overall perspectives on learners with RWD and findings in literature.

Mauritius is progressing towards implementing an inclusive education approach for all learners with special education needs, which includes those experiencing difficulties with reading and writing skills in regular classrooms. At the primary education level, teachers play a vital role in early identification of learners with any form of RWD so that they may be able to achieve with appropriate support in an inclusive classroom (Essa \& El-Zeftawy 2015:79; Gandhimathi \& Eljo 2010:77). To better support learners with RWD, teachers must be equipped with adequate knowledge about identification and intervention of learners with RWD in an inclusive education setting (Shukla \& Agrawal 2015:37). The current study revealed the detailed perspectives of a sample of mainstream primary school teachers in Mauritius on their training and experiences of learners with RWD, their views on inclusive education and self-reported strategies they would use to support learners. Significant associations were found between certain participant demographics and views expressed in the survey questionnaire. Additional associations were found between those participants who reported that they were confident to identify learners with RWD and those who stated that they lacked knowledge to intervene with learners with RWD in the classroom and views on learners with RWD in their classrooms. Factor analysis highlighted the importance given to certain statements as they were summarised under specific factors.

The demographic characteristics of the 100 participants showed that they were mostly female with a mean age of almost 37 years, mostly well qualified with bachelor or higher degrees and teaching experience of more than 10 years. Even though they are accomplished teachers, and almost all had encountered learners with RWD, participants had no training about the role of speech-language therapists and audiologists in schools except for an orientation on communication disorders and RWD. Almost all participants had encountered learners with RWD in their teaching. The results are consistent with those of Gündoğmuş (2018:337) and Dapudong (2014:7) who also found that mainstream primary school teachers working in an inclusive education system in Turkey and Thailand had not received any orientation or training in special education.

The participants' lack of training was further reflected in their limited views on the wide variety of causes of RWD and diagnostic terms related to underlying causes. They rated intellectual disability and lack of parental involvement in 
their child's education as main contributing factors for RWD. In similar studies, teachers reported that family variables were amongst the causes of RWD, thereby assigning the family with the greatest share of responsibility in assisting learners with RWD (Gündoğmuş 2018:336). However, participants were less familiar with conditions like specific learning disorders, auditory processing difficulties and attention-deficit hyperactivity disorder which largely contribute to RWD and the need for specific interventions (American Psychiatric Association 2013:59-74; Fienup et al. 2015:97; Küçükünal, Özçelik \& Yalçınkaya 2020:2). Being knowledgeable about all possible underlying causes of RWD is important for teachers so that they can identify their learners' difficulties, detect the degree of severity and develop intervention strategies in the educational context for these learners (Gonçalves \& Crenitte 2014:827; Henrique \& Madeira 2017:2495). Several authors point out that a lack of training related to RWD may jeopardise early identification and subsequent interventions of learners with RWD in an inclusive education setting (Alnaim 2015:1043; Essa \& El-Zeftawy 2015:80; Saravanabavan \& Saravanabavan 2010:136). Once a learner is identified with RWD, it is important that the teacher engages in an appropriate intervention by following the correct referral course to other professionals.

In the current study, the majority of participants reported that they do not have sufficient knowledge about intervention of learners with RWD to support them. Participants were also not familiar with the multidisciplinary team involved in the assessment, diagnosis and intervention of learners with RWD. Research supports the need for referral to qualified professionals for evidence-based evaluations and interventions that are necessary for achieving optimal outcomes for learners with RWD (Kathard et al. 2011:66; Wium \& Louw 2013:34). Participants' lack of experience with the multidisciplinary team is to be expected as they received no training regarding intervention of RWD, and there is also a shortage of these professionals in Mauritius. The results clearly emphasise the need to train teachers about the functions of the multidisciplinary team around the learner with RWD and their own role in the collaboration (Mitchell 2015:25; Nascimento, Rosa \& Queiroga 2018:92). The aim of the inclusive education approach is to include these learners within the educational system and provide them with the necessary support to enter and remain within the system (Mitchell 2015:11). This can only be done through the implementation of several learning strategies to fulfill the needs of the diversity of learners (Mosquera, Cárdenas \& Claudia Nieto 2018:332). The use of adapted books, curriculum and assessment tools are important strategies for learners with RWD (Kafongo \& Balli 2013:62). Inclusive education practice involving inter- and intra-professional collaboration with educational psychologists and other therapists within school practice is considered as an integral part of the intervention for learners with RWD (Lütje-Klose \& Urban 2014:291). With appropriate therapeutic intervention and teaching methods, many learners with RWD can develop literacy skills and meet academic demands (Gillon et al. 2019:2009).

Most participants identified certain characteristics about learners with RWD that may facilitate their inclusion in regular classrooms. According to Gindrich and Kazanowski (2017:2), learners with RWD can be more creative at art, music and other extracurricular activities even if they have significant difficulties mastering reading and writing skills. Similar to Lopes and Crenitte (2013:1221), participants observed that learners with RWD often try harder to read and to complete their class/homework on their own. However, participants anticipated that learners with RWD may display behaviour problems in regular classrooms (Cavioni, Grazzani \& Ornaghi 2017:101). Typically, achieving learners may act as role models for those with RWD, thereby promoting understanding and acceptance of different learners (Hayes \& Bulat 2017:5). The participants' recognition of favourable characteristics of learners with RWD is a starting point for training. It may help teachers and typically achieving learners to develop a more balanced view of learners with RWD in their class, thereby facilitating the integration of learners with RWD. Similar to the findings of Cretu and Morandau (2020:23), the current study also found that younger participants were more interested in training to support learners with RWD in an inclusive education system. Furthermore, experienced teachers amongst the participants tended to view learners with RWD more positively and agreed that they needed extensive training.

In contrast, most of the participant responses indicated that learners with RWD should be in a special education needs school as their academic growth will be restricted in a regular classroom. Participants also viewed inclusive education as detrimental to learners with RWD. Only $18.2 \%$ of participants expressed a view to support inclusive education. The most common explanation for this point of view in other studies is the large teacher-student ratio in regular classrooms, the lack of time to give special attention to learners with RWD or to adapt teaching tools (Florian 2012:277). In the current study, $74 \%$ of participants were teaching large numbers of $25-34$ and more learners (see Table 1). However, similar to other studies, the current participants tended to agree that an inclusive education setting may foster a better understanding and acceptance of differences amongst learners as social isolation may be eliminated (Beacham \& Rousse 2012:3; Costello \& Boyle 2013:130; Lüke \& Grosche 2018:435). Even though a clear preference for special education was expressed, the majority of participants were willing to accommodate learners with RWD in their classrooms provided that they receive extensive retraining to support these learners to achieve literacy goals. The views of participants regarding inclusive education are in agreement with studies that show that teachers felt less able to meet the needs of learners with RWD and that they had insufficient knowledge to teach them (Alahmadi \& El Keshky 2019:18; Gonzalves \& Crenitte 2014:825; Lingeswaran 2013:4). Factor analysis showed that the most important components for the study were the participants, which indicated that learners with RWD may be included in regular classrooms 
when teachers are adequately trained in inclusive education. This perspective indicates that teacher training in inclusive education principles and strategies can be favourably received.

When participants described support strategies that may assist learners with RWD in a regular classroom, their responses showed how resourceful they were despite no training. However, strategies that could be employed within the classroom were limited. Participants focused more on increasing the learners' reading and writing outcomes by using one-on-one instruction, which may not be the best approach according to various studies (Amendum, VernonFeagans \& Ginsberg 2011:108; Vernon-Feagans et al. 2013:1177).

Some limitations and strengths of the present study can be addressed. The survey questionnaire used in the study could have included more questions about inclusive education for learners with RWD. However, when used in future research, the same questionnaire may indicate changes in perspectives of mainstream primary school teachers after training sessions and implementation of inclusive education for learners with RWD in Mauritius. The principle component analysis highlighted the importance that we have lent to certain statements as they were summarised under specific factors.

\section{Conclusion}

It would be justified to say that the perspectives of regular classroom teachers towards educational inclusion are key to include learners with RWD in regular schools (Joshi, Washburn \& Kahn-Horwitz 2016:1; Pit-ten Cate et al. 2018:50). The results of the current study should be viewed against the background of participants who are well qualified as teachers but with no training in inclusive education or how to assist learners with RWD in a regular classroom. It is, therefore, no surprise that they consider special education schools as the best learning environment for learners with RWD instead of regular classrooms. Training will increase teachers' confidence in their identification and teaching practices, thereby encouraging them to create more engaging learning environments for learners with RWD (Bell, McPhillips, \& Doveston 2011:187; Gwernan-Jones \& Burden 2010:80; Washburn et al. 2017:137). The study supports the need for in-service training of mainstream primary school teachers in RWD and inclusive education and to include the topics in the curriculum of future teachers in Mauritius. Such training may be favourably viewed by teachers. More research should be conducted to investigate the perspectives of school principals, support teachers and the multidisciplinary team on learners with RWD in mainstream schools as they are important sources of information. This will provide a wide range of perspectives to policy makers to improve education and support for learners with RWD and to accelerate the implementation of inclusive education in Mauritius.

\section{Acknowledgements}

The authors would like to thank the teachers who participated in this study.

\section{Competing interests}

The authors declare that they have no financial or personal relationships that may have inappropriately influenced them in writing this article.

\section{Authors' contributions}

Both S.V. and A.K. authors planned the study; S.V. collected the data and wrote the article. A.K. reviewed the manuscript. S.T.R. carried out the statistical analysis and reviewed the manuscript. All authors provided critical feedback and helped shape the research, analysis and manuscript.

\section{Funding information}

The authors received no financial support for the research, authorship and or publication of this article.

\section{Data availability}

The data that support the findings of this study are available from the corresponding author, (S.V.), upon request.

\section{Disclaimer}

The views and opinions expressed in this article are those of the authors and do not necessarily reflect the official policy or position of any affiliated agency of the authors.

\section{References}

Alahmadi, N.A. \& El Keshky, M.E.S, 2019, 'Assessing primary school teachers' knowledge of specific learning disabilities in the Kingdom of Saudi Arabia', Journal of Educational and Developmental Psychology 9(1), 9-22. https://doi. org/10.5539/jedp.v9n1p9

Alawadh, A., 2016, 'Teachers' perceptions of the challenges related to provision of services for learners with specific learning difficulties (dyslexia) in Kuwaiti government primary schools', Doctoral dissertation, University of York, viewed 12 March 2019, from http://etheses.whiterose.ac.uk/id/eprint/17437.

Allen, M.H., Matthews, C.E. \& Parsons, S.A., 2013, 'A second-grade teacher's adaptive teaching during an integrated science-literacy unit', Teaching and Teacher Education 35, 114-125. https://doi.org/10.1016/j.tate.2013.06.002

Alnaim, F., 2015, 'Learning disabilities concept and identification: Primary teachers' perspectives in Saudi Arabia', International Journal of Social Science and Humanity 5(12), 1040. https://doi.org/10.7763/IJSSH.2015.V5.601

Amendum, S.J., Vernon-Feagans, L. \& Ginsberg, M.C., 2011, 'The effectiveness of a technologically facilitated classroom-based early reading intervention: The targeted reading intervention', The Elementary School Journal 112(1), 107-131. https://doi.org/10.1086/660684

American Psychiatric Association, 2013, Diagnostic and statistical manual of mental disorders (DSM-5), American Psychiatric Association, Arlington, TX.

Ateş, S., Yildirim, K. \& Yildiz, M., 2010, 'Opinions of classroom teachers and prospective classroom teachers about the learning difficulties encountered in the teaching process of reading and writing', Elementary Education Online 9(1), 44-51.

Austin, C.R. \& Vaughn, S., 2019, 'Reading interventions for young learners with reading difficulties and disabilities: The role of word reading and word meaning', Special Education for Young Learners with Disabilities: Advances in Specia Education 34, 15-37. https://doi.org/10.1108/S0270-401320190000034002

Beacham, N. \& Rouse, M., 2012, 'Student teachers' attitudes and beliefs about inclusion and inclusive practice', Journal of Research in Special Educational Needs 12(1), 3-11. https://doi.org/10.1111/j.1471-3802.2010.01194.x

Bell, S., McPhillips, T. \& Doveston, M., 2011, 'How do teachers in Ireland and England conceptualise dyslexia?', Journal of Research in Reading 34(2), 171-192. https:// doi.org/10.1111/j.1467-9817.2009.01419.x

Cavioni, V., Grazzani, I. \& Ornaghi, V., 2017, 'Social and emotional learning for children with learning disability: Implications for inclusion', International Journal of Emotional Education 9(2), 100-109.

Costello, S. \& Boyle, C., 2013, 'Pre-service secondary teachers' attitudes towards inclusive education', Australian Journal of Teacher Education 38(4), 129-143. https://doi.org/10.14221/ajte.2013v38n4.8 
Cretu, D.M. \& Morandau, F., 2020, 'Initial teacher education for inclusive education: A bibliometric analysis of educational research', Sustainability 12(12), 4923. https:// bibliometric analysis of educa
doi.org $10.3390 /$ su12124923

Dapudong, R.C., 2014, 'Teachers' knowledge and attitude towards inclusive education: Basis for an enhanced professional development program', International Journa of Learning \& Development 4(4), 1-24. https://doi.org/10.5296/ijld.v4i4.6116

Education Statistics-2017 of Republic of Mauritius, 2018, Education Statistics-2017 viewed 30 January 2019, from https://statsmauritius.govmu.org/Documents/ Statistics/ESI/2017/EI1337/Edu_Yr17.pdf.

Essa, H.A. \& El-Zeftawy, A.M.A., 2015, 'Teachers' knowledge, attitudes and reported strategies to assess and support the students with learning difficulties', Journal of Nursing and Health Science 4(2), 79-92.

Fienup, D.M., Reyes-Giordano, K., Wolosik, K., Aghjayan, A. \& Chacko, A., 2015, 'Brief experimental analysis of reading deficits for children with attention-deficit/ hyperactivity disorder', Behavior Modification 39(1), 191-214. https://doi. org/10.1177/0145445514550393

Florian, L., 2012, 'Preparing teachers to work in inclusive classrooms: Key lessons for the professional development of teacher educators from Scotland's inclusive practice project', Journal of Teacher Education 63(4), 275-285. https://doi. org/10.1177/0022487112447112

Gandhimathi, U. \& Eljo, J.O., 2010, 'Awareness about learning disabilities among the primary school teachers', Cauvery Research Journal 3(1), 71-78, viewed 22 December 2020, from http://cauverycollege.ac.in/Admin/FileFolder/Journals/ 77.pdf.

Gillon, G., McNeill, B., Scott, A., Denston, A., Wilson, L., Carson, K. et al., 2019, 'A better start to literacy learning: Findings from a teacher-implemented intervention in children's first year at school', Reading and Writing 32(8), 1989-2012. https:// in children's first year at school', Readin
doi.org/10.1007/s11145-018-9933-7

Gindrich, P.A. \& Kazanowski, Z., 2017, 'The creative potential and self-reported learning disabilities of polish university students who major in special education', SAGE Open 7(1), 1-12. https://doi.org/10.1177/2158244016689128

Gonçalves, T.D.S. \& Crenitte, P.A., 2014, 'Conceptions of elementary school teachers about learning disorders', Revista CEFAC 16(3), 817-829. https://doi. org/10.1590/1982-0216201427312

Gündogmus, H.D., 2018, 'The difficulties experienced by teachers in the process of primary reading and writing instruction and their solution offers for eliminatin these difficulties', Universal Journal of Educational Research 6(2), 333-339. https://doi.org/10.13189/ujer.2018.060216

Gwernan-Jones, R. \& Burden, R.L., 2010, 'Are they just lazy? Student teachers' attitudes about dyslexia', Dyslexia 16(1), 66-86. https://doi.org/10.1002/dys.393

Hayes, A.M. \& Bulat, J., 2017, Disabilities inclusive education systems and policies guide for low- and middle-income countries, RTI Press Publication No. OP-00431707, RTI Press, Research Triangle Park, NC, viewed 13 February 2021, from https://doi.org/10.3768/rtipress.2017.op.0043.1707

Henrique, M.R. \& Madeira, M.L., 2017, 'Reading and writing: Learning difficulties, causes and teacher's intervention' Literacy Information and Computer Education Journal 8(1), 2489-2496. https://doi.org/10.20533/licej.2040.2589.2017.0331

Hollenweger, J., 2011, 'Teachers' ability to assess students for teaching and supporting learning', Prospects 41(3), 445-457. https://doi.org/10.1007/s11125-011-9197-3

Joshi, R.M., Washburn, E.K. \& Kahn-Horwitz, J., 2016, 'Introduction to the special issue on teacher knowledge from an international perspective', Annals of Dyslexia 66(1), 1-6. https://doi.org/10.1007/s11881-015-0119-6

Kafonogo, F.M. \& Bali, T.A., 2013, 'Exploring classroom teachers' awareness of pupils with learning disabilities: Focusing on public primary schools in Tanzania', Journal of Education and Practice 4(24), 58-66, viewed 05 January 2021, from https:// iiste.org/Journals/index.php/JEP/article/view/8897/9171

Kamala, R. \& Ramganesh, E., 2013, 'Knowledge of specific learning disabilities among teacher educators in Puducherry, Union Territory in India', International Review of Social Sciences and Humanities 6(1), 168-175. https://doi.org/10.5463/dcid. v26i3.443

Kathard, H., Ramma, L., Pascoe, M., Jordaan, H., Moonsamy, S., Wium, A.M. et al., 2011 'How can speech-language therapists and audiologists enhance language and literacy outcomes in South Africa? (And why we urgently need to)', South African Journal of Communication Disorders 58 (2), a27. https://doi.org/10.4102/sajcd.v58i2.27

Küçükünal, I.S., Özçelik, A.D.Ö. \& Yalçınkaya, F., 2020, 'Teachers' opinions regarding the symptoms of central auditory processing disorder in children with reading and writing difficulties', South African Journal of Education 40(2), 1-9. https://doi. org/10.15700/saje.v40n2a1640

Lingeswaran, A., 2013, 'Assessing knowledge of primary school teachers on specific learning disabilities in two schools in India', Journal of Education and Health Promotion 2, 1-5. https://doi.org/10.4103/2277-9531.115807
Lopes, R.C.F. \& Crenitte, P.A.P., 2013, 'Analytical study of teachers' knowledge about learning disorders', Revista CEFAC 15(5), 1214-1226. https://doi.org/10.1590/ S1516-18462012005000091

Lüke, T. \& Grosche, M., 2018, 'Implicitly measuring attitudes towards inclusive education: A new attitude test based on single-target implicit associations', European Journal of Special Needs Education 33(3), 427-436. https://doi.org/10. 1080/08856257.2017.1334432

Lütje-Klose, B. \& Urban, M., 2014, 'Professionelle Kooperation als wesentliche BedingunginklusiverSchul-und Unterrichtsentwicklung Teil 2: Forschungsergebnisse zu intra- und interprofessioneller Kooperation [Cooperation as an essential zu intra- und interprofessioneller Kooperation [Cooperation as an essentia condition for inclusive education development processes - Outcomes of research
concerning inter- and intra-professional cooperation]', Vierteljahresschrift Für concerning inter- and intra-professional cooperation]', Vierteljahresschrift Für
Heilpädagogik Und Ihre Nachbargebiete 83, 283-294. https://doi.org/10.2378/ veilpädagogik

Ministry of Education and Human Resources, 2006, National curriculum framework primary (NCFP2006), viewed 30 January 2019, from http://www.gov.mu/portal/ site/education/menuitem.4b83e1c0ffc5b504631e691048a521ca/.

Ministry of Education and Human Resources, 2017, Salient features of inclusive education for children and youth with special needs in Mauritius: Concept to reality: Policy framework and strategy document, viewed 30 January 2019, from https://education.govmu.org/Documents/educationsector/Documents/ Special\%20Education\%20Needs/SEN_Strategy_2017_Final.pdf.

Mitchell, D., 2015, 'Inclusive education is a multi-faceted concept', Center for Educational Policy Studies Journal 5(1), 9-30.

Mosquera, Ó.A., Cárdenas, M.L. \& Claudia Nieto, M., 2018, ‘Pedagogical and research approaches in inclusive education in ELT in Colombia: Perspectives from some profile journal authors', Profile Issues in Teachers Professional Development 20(2), 231-246. https://doi.org/10.15446/profile.v20n2.72992

Nascimento, I.S.D., Rosal, A.G.C. \& Queiroga, B.A.M.D., 2018, 'Elementary school teachers' knowledge on dyslexia', Revista Cefac 20(1), 87-94. https://doi. org/10.1590/1982-021620182019117

Paterlini, L.S.M., Zuanetti, P.A., Pontes-Fernandes, A.C., Fukuda, M.T.H. \& Hamad, A.P.A., 2019, 'Screening and diagnosis of learning disabilities/disorders-outcomes of interdisciplinary assessments', Revista CEFAC 21(5), 1-8. https://doi.org/ 10.1590/1982-0216/201921513319

Pit-ten Cate, I.M., Markova, M., Krischler, M. \& Krolak-Schwerdt, S., 2018, 'Promoting inclusive education: The role of teachers' competence and attitudes', Insights into Learning Disabilities 15(1), 49-63, viewed 20 February 2020, from https://files. eric.ed.gov/fulltext/EJ1182863.pdf.

Saravanabhavan, S. \& Saravanabhavan, R.C., 2010, 'Knowledge of learning disability among pre-and in-service teachers in India', International Journal of Special Education 25(3), 132-138, viewed 04 December 2020, from https://files.eric.ed. gov/fulltext/EJ909291.pdf.

Shukla, P. \& Agrawal, G., 2015, 'Awareness of learning disabilities among teachers of primary schools', Online Journal of Multidisciplinary Research 1(1), 33-38.

UNESCO, 1994, 'The Salamanca statement and framework for action on special needs education: Adopted by the world conference on special needs education: Access and quality', UNESCO, Salamanca, Spain, June 7-10, 1994, pp. 1-22.

UNESCO, 2005, Guidelines for inclusion: Ensuring access to education for all, UNESCO viewed 30 January 2019, from http://www.ibe.unesco.org/sites/default/files/ Guidelines_for_Inclusion_UNESCO_2006.pdf.

Vasudevan, A., 2017, 'Slow learners-causes, problems and educational programmes', International Journal of Applied Research 3(12), 308-313, viewed 15 December 2020, from https://www.allresearchjournal.com/archives/?year=2017\&vol=3\&iss ue=12\&part $=E \&$ Articleld $=4656$.

Vaughn, M. \& Parsons, S.A., 2013, 'Adaptive teachers as innovators: Instructional adaptations opening spaces for enhanced literacy learning', Language Arts $91(2), 81-93$, viewed 20 December 2020, from http://www.jstor.org/stable/ 24575032

Vernon-Feagans, L, Kainz, K. Hedrick, A. Ginsberg, M. \& Amendum, S., 2013, ‘Live webcam coaching to help early elementary classroom teachers provide effective literacy instruction for struggling readers: The targeted reading intervention,
Journal of Educational Psychology 105(4), 1175-1187. https://doi.org/10.1037/ a0032143

Washburn, E.K., Mulcahy, C.A., Musante, G. \& Joshi, R., 2017, 'Novice teachers' knowledge of reading-related disabilities and dyslexia', Learning Disabilities: A Contemporary Journal 15(2), 169-191.

Wium, A.M. \& Louw, B., 2013, 'Revisiting the roles and responsibilities of speechlanguage therapists in South African schools', South African Journal of Communication Disorders 60(1), 31-37. https://doi.org/10.4102/sajcd.v60i1.8 